\title{
Smallholder Farmers' Responses to Scientific Early Warning on Weather in the Okavango Delta, Botswana
}

\author{
Oluwatoyin Dare Kolawole ${ }^{1}$, Moseki Ronald Motsholapheko ${ }^{1}$, Barbara Ntombi Ngwenya ${ }^{1}$, Ananias Moses ${ }^{1}$, \\ Melda Nonhle Makebea ${ }^{1} \&$ Matshidiso Tshidi Kaisara ${ }^{1}$ \\ ${ }^{1}$ Okavango Research Institute, University of Botswana, Maun, Botswana \\ Correspondence: Oluwatoyin Dare Kolawole, Okavango Research Institute, University of Botswana, P/Bag 285 \\ Maun, Botswana. E-mail: tkolawole@ub.ac.bw
}

Received: May 9, 2018

doi:10.5539/jsd.v11n6p82
Accepted: July 12, $2018 \quad$ Online Published: November 29, 2018

URL: https://doi.org/10.5539/jsd.v11n6p82

\begin{abstract}
Although formal channels of communication exist for conveying early warning scientific weather messages, it is widely believed that small-scale farmers continue to utilize traditional practices in obtaining weather information. This study identifies and assesses the factors which influence the uptake of scientific early warning weather information by small farmers in the Okavango Delta, Botswana. A descriptive-analytical design was used to study 90 farmers in Kareng and Bodibeng communities situated within the delta basin. A multi-stage sampling procedure was used to select the sample from an existing household listing. A semi-structured interview and focus group discussion (FGD) were used to elicit information from the respondents. Findings show that most farmers $(68.9 \%)$ moderately utilize scientific weather information, while $16.7 \%$ had a low uptake of the messages. Nonetheless, $14.4 \%$ of farmers had a high uptake of weather information. There was significant positive correlation, at $p \leqslant 0.01$ confidence level, between uptake of early warning scientific weather information and educational level, age, traditionalism and fatalism. The uptake of scientific weather information or messages had a strong association with information sources such as Kgotla meetings, TV, print media, agricultural extension agents and the radio. The uptake of modern scientific weather information needs to be promoted through these modes of communication, coupled with well-resourced extension services, and in ways that may not be perceived to denigrate indigenous knowledge. Sectoral departments should collaborate in addressing existing challenges for appropriate climate response action.
\end{abstract}

Keywords: farmers, indigenous knowledge, information uptake, science, weather forecast

\section{Introduction}

About 630 million hectares of land in Africa is suitable for farming, supporting most people through subsistence and commercial farming (FAO, 2001, cited in Osabuohien, 2014). In sub-Saharan Africa agriculture is the economic mainstay of about $70 \%$ of the population (Thornton et al., 2003). Agricultural productivity is closely linked to environmental factors such as soil quality and water availability (Chenje, 2002). In most parts of Africa, desertification, soil infertility, unpredictable and unreliable rainfall, and weather variations are often identified as impediments in agricultural food production.

In Botswana $70 \%$ of rural households depend on agricultural production for subsistence purposes (Seanama Conservation Consultancy, 2012). Yet, the agricultural sector contributes about $2.2 \%$ of the total Gross Domestic Product (GDP) (Statistics Botswana, 2016). Indeed, agriculture in Botswana is plagued by numerous factors such as poor soil fertility and unreliable rainfall. This is one of the main reasons behind the agricultural industry's inability to meet the adequate amount of food supply in the country. Land tenure, use of technology, and marketing of agricultural outputs separate small farmers from their commercial counterparts. While the smallholders live in communal lands where they practice mixed farming and depend on rain-fed agriculture, the commercial farmers, who constitute about $1 \%$ of the total number of farmers, occupy medium to large scale farms on freehold land and apply modern and capital intensive farming techniques, including irrigation (Bendsen $\&$ Meyer, 2002).

Local farmers' agricultural production is determined mostly by changes in weather conditions. In recent times, more attention has been paid to climate change due to the sharp variations in global weather conditions. The Department of Meteorological Services and other stakeholders endeavor to provide early warning scientific 
weather information which helps in predicting weather changes and anticipating possible impacts. These weather forecasts are meant to assist farmers to make informed decisions regarding farming practices such as the type of crops to grow in a season.

\section{Uptake of Scientific Weather Information versus Local Knowledge}

Local knowledge (LK) or indigenous knowledge (IK) is used interchangeably to connote a context-specific knowledge developed by a given community in a geographical location (Grenier, 1998) as opposed to the scientific knowledge developed in conventional research institutions, universities and private industries (Warren 1991; Chambers et al., 1989). IK is also defined as "the 'technical' insight or wisdom gained and developed by people in a particular locality, through years of careful observation and experimentation with the natural phenomena around them" (Kolawole, 2001: p13). Based on various definitions of the concept, it is generally conceived as geographically located and context-specific in nature. LK or IK thus serves as the basis for local level development (Kolawole, 2015; 2009; Dewes, 1993). There are numerous factors influencing the uptake of scientific weather information by local farmers, but the most prominent ones are traditionalism, fatalism and preference for the use of LK (Kolawole, 2015; 2003). While traditionalism is a value orientation that predisposes people to stick to their old ways of doing things (Kolawole, 2001; Ogburn, 1950), fatalism connotes the tendency or a personal philosophy which makes an individual to resign to fate or prevailing external circumstances (Kolawole et al., 2003; Beal et al., 1968). Both traditionalism and fatalism are not mutually exclusive. While traditionalism confines a people to a certain lifestyle and which, to a considerable degree, shapes how they view their world, fatalism drives people's inaction in their response to some phenomena occurring within their immediate environment (Kolawole, 2006; Kolawole et al., 2003; Beal et al., 1968). These value orientations play a significant role in the way farmers respond to new information or technology introduced to them at any point in time.

In Tswana traditional society, rain and rain-making ceremonies were of crucial importance. The Kgosi (Chief), religious leaders and rainmaking specialists (Baroka pula) have the traditional obligation to ensure that the community members participate in annual prayers and rain ceremonies, followed by customary declaration of the start of the ploughing season (Go rebola letsema). When good rains come, this is regarded as a blessing from God and for some, the ancestors who were appeased by some ritual performance. Failure of rain in a society indicated that the land was impure, bewitched or that God or ancestors were not happy hence cursing the land. Magic was not always evil; there was a positive side of magic. Among the positive use of magic was to improve the fertility of the soil and livestock. Magic was also used to reveal the past, present and predicting the future (Gewald, 2001).

There are many ways of interpreting and predicting the weather and they vary by culture. Some people use flower and fruit production to forecast rainfall. Scanty rains can be taken as the sign that God and the spirits of the ancestors are displeased with local people because of their conduct; in contrast, abundant rains can indicate divine or cosmological favor (Orlove et al., 2010). Good yield from some trees predict abundant rainfall and a favorable season and others predict drought resistant crops, such as millet will yield more than sorghum. Audible sounds (like thunderstorms) could also be used to predict rainfall, and community people look at the dark clouds (Onyango, 2009). With other indicators, such as increase in night temperatures, shift in direction of prevailing winds, flowering of trees, phases of the moon and certain birds, it is possible for local people to predict the rains. Roncoli, Ingram and Kirshen (2002) observe that 'Changes in star and moon appearance provide a framework for sequences of expected rain events that mark key points in crop growth.' Whirlwinds can also be used to determine rain as they are thought to demonstrate good spirits of the gods. Ring around the sun could also be used to predict rain as it is used to decide irrigation, labor arrangement and fertilizer application. Environmental indicators can be learned by the exchange of information from one person to another, usually from the adults to the children. The elderly male farmers are the ones who usually pass down the knowledge about weather predictions down to the young ones through observations, folk songs and casual conservation.

Environmental factors have determined the kinds of crops and animals that can be raised in the country. The meteorological department, which is responsible for disseminating information, is often seen as being out of touch with the realities of agricultural life, recommending higher levels of inputs than farmers can afford, and insisting on rigid schedules which take no account of climatic variability. The dissemination of forecasts in such a vacuum is likely to exacerbate the low levels of trust that already exist (Blench, 1999). Generally, factors contributing to this problem can be classified as socio-cultural, socio-economic, institutional and environmental in nature. In Botswana, scientific weather information seems to be inadequate as farmers find it difficult to either access weather information or adopt them for making informed decision in their farming activities. Other possible socio-cultural factors are language barrier, inadequate awareness and low levels of education. Most 
local farmers have not received formal education hence they may find scientific weather information incomprehensible and inapplicable to them. The way in which weather forecast information is disseminated; such as through the radio, printed media or through word of mouth, influences how people react to the information and the quality of information that is passed on. The lack of efficiency in delivery often creates a problem. The time delay from when the forecast is issued to when the forecast reaches the users is known as the time lag (Perrings \& Stern, 2000; Stern \& Easterling, 1999).

The forecasts may be poorly disseminated, being delivered at short notice, and not regularly reaching smallholder farmers in locally comprehensible form. Some farmers have little confidence in the reliability of rainfall and therefore choose not to plant longer cycle crops. Farmers are always faced with an arduous task of selecting the area of farming and choosing the right time. Some wait till the soil is moist enough to determine whether it will be good enough for ploughing. They take into consideration the soil and landscape positions. The credibility of the forecast, built on the accuracy of past forecasts and the forecast communicators' reputation, can also restrict the uptake of information (Ziervogel, 2004). Improved credibility may depend on improved forecasts and better data or may depend on better communication that emphasizes the probabilistic nature of the forecast. Weak institutions and poor infrastructure influence the uptake of weather scientific information. Hence there are inadequate information dissemination strategies and there is no mutual relationship between meteorological services and the local farmers. Knowing the local community people's dynamics of knowledge production is essential for optimal synergy and healthy relationship amongst development practitioners and local farmers alike (Kolawole, 2013).

There is dearth of knowledge on uptake of early warning messages in Botswana. Therefore, this research paves a way for further explorations of other possible factors. This study, a) investigates factors influencing local farmers' decisions and choices in the uptake of early warning in agricultural production, b) examines communities' perception about scientific weather information and climate change, and c) determines the relationship between the affinity for utilizing indigenous knowledge (IK) in weather prediction and the uptake of early warning scientific weather information in the Okavango Delta, Botswana.

\section{Study Area}

According to the CSO (2011), 14.5\% of the population of Ngamiland District rely on agricultural production; farming is the most important livelihood activity for over $23 \%$ of households in rural areas of the Okavango. Pastoral farming is concentrated in areas such as Maun/Shorobe, Toteng/Sehithwa/Tsau, Nokaneng/Gumare, Shakawe, and Seronga. Dry land farming is the major farming system in Ngamiland District practiced by $85 \%$ of the farming households. Molapo cultivation is found in the floodplains at the western and south eastern fringes of the Okavango Delta, mainly in Tubu and in the Shorobe-Matlapana area (Bendsen \& Meyer, 2002).

Traditional arable farming (mixed cropping) is widely practiced but does not yield major outputs due to irregular environmental and or weather conditions during the cropping season, which are beyond the control of farmers. As the natural conditions change radically, yields vary considerably from crop to crop, from year to year and place to place during the cropping season. Traditional farming is flexible as farmers can switch to more drought resistant crops in periods of low flooding or persistent low rainfall. Farmers have been frequently hit by disasters such as floods, disease outbreaks and droughts, which result in low crop production and high livestock mortality. The livestock sector in Ngamiland District has always been threatened by a number of trans-boundary diseases, such as foot and mouth disease (FMD), contagious bovine pleuro-pneumonia (CBPP), and African animal trypanosomiasis (Bendsen \& Meyer, 2002).

The research was conducted in two selected villages, which are Bodibeng and Kareng situated within the Ngamiland District in the north-western part of Botswana. Most people in Ngamiland District diversify income generation systems by getting involved in rain-fed and flood recession cultivation, livestock management, fishing, hunting, gathering of veld products, small-scale commercial enterprises like the production and sale of crafts and local food and beverages, wage labor in the tourism industry, and formal employment in the government and in the private sector (Bendsen \& Meyer, 2002).

The two villages are in an area with rich abundance of livestock rearing and arable farming. The areas, from Lake Ngami and eastward to Toteng, primarily used as grazing land only intermixed with small arable fields. The areas from Nokaneng southwards, westwards up to Kareng and Bodibeng, and the rangeland around Lake Ngami up to Tsau are the foremost livestock-rearing areas. Kareng and Bodibeng have populations of 1259 and 778 people respectively (CSO, 2011). The BaHerero are the dominant ethnic group. The BaTawana are also primary livestock farmers, but simultaneously practice dryland farming around the Toteng and the Maun area. Therefore, Bodibeng and Kareng are chosen as the study areas because they are farming communities and thus make up an 
appropriate study population.

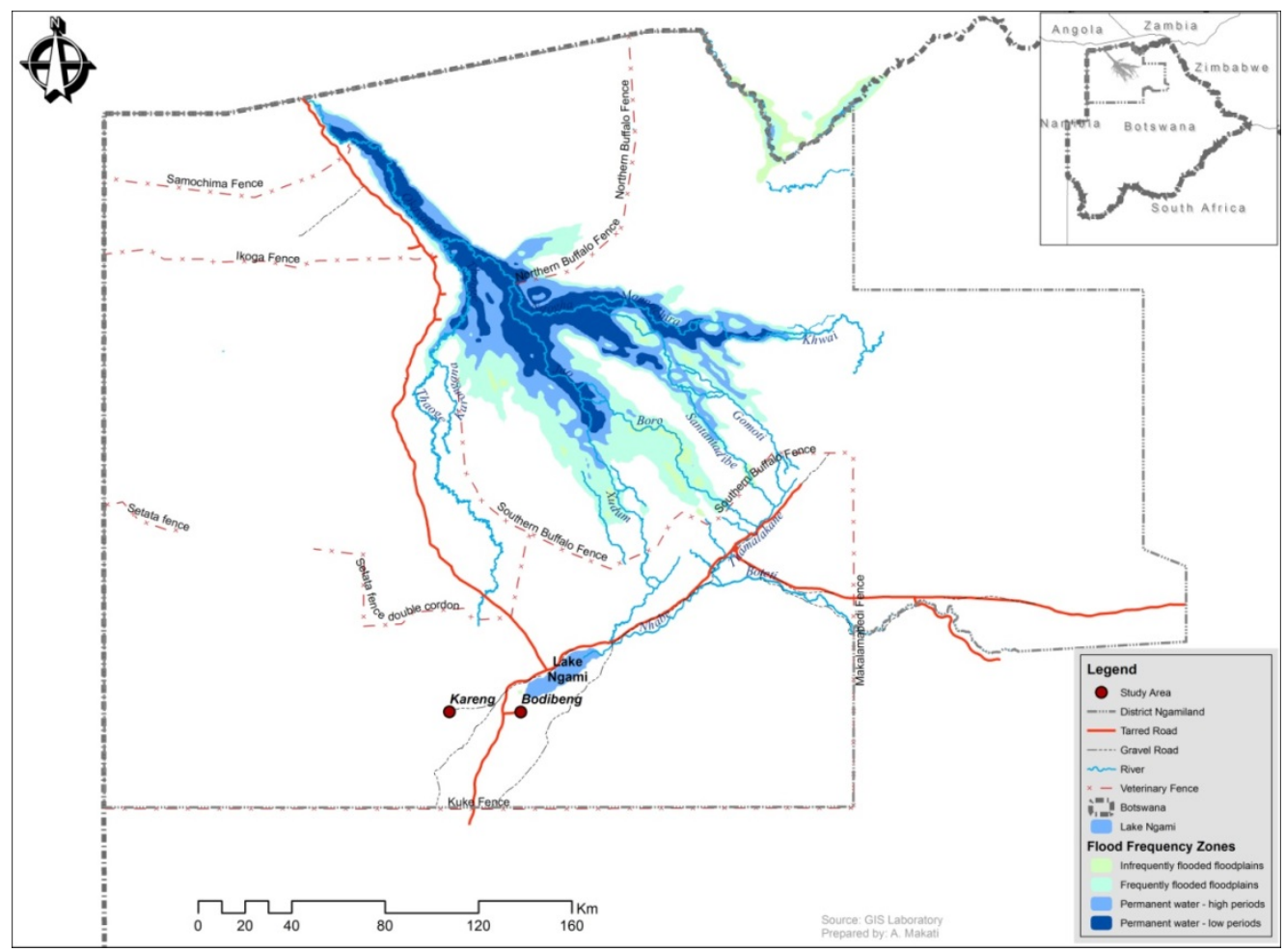

Figure 1. Map of the Okavango Delta showing the study areas

\section{Methods}

This was a descriptive and analytical study designed to assess the factors influencing the uptake of early warning scientific weather information by local farmers. A multi-stage sampling procedure was used to select households in the villages of Bodibeng and Kareng. First, the selection of communities was purposive. Second, proportionate sampling was used to sample the number of respondents in each of the two communities in relation to the household's number. Simple random sampling was used to select specific farming households from whom weather and farming information would be elicited. With proportionate sampling, 42 households in Bodibeng were selected from a total of 134 households and 48 households from a total of 151 households in Kareng. In each study area, some 6-12 farmers were selected for focus group discussions (FGDs) and the rest were interviewed using an interview schedule. In total, 90 farmers (constituting about $32 \%$ of the entire population), including the Kgosi as well as members of the farmers' committee were interviewed.

\subsection{Data Collection Techniques and Instrumentation}

The interview schedule for households and interview guide for focus group discussion were pre-tested at Nxaraga for reliability and validity. The tools used for data collection included cameras, tape recorders, interview schedules and interview guides. The techniques used were focus group discussion (FGD) sessions and interviews. An interview schedule was used for collecting open- and close-ended information. It contained three parts; opening, body and closing. The opening contained the objective of the interview and made the respondents feel at ease, the body consisted of topics and questions, and the closing part allowed the interviewee to give final comments. Our research required the use of an interview schedule as some of the farmers were illiterate. The interview was also used to obtain data from key informants, who were mostly elderly people (age above 50) and in each study area, ten farmers were interviewed. This schedule covered mostly their perceptions on indigenous knowledge and its influence on their uptake of scientific weather information, as well as their beliefs, practices and norms related to weather prediction.

FGD is a participatory approach for qualitative information gathering and it usually comprises between six to twelve people. It allows attendants to freely express themselves as there is flexibility in the spoken language. An interview guide is used to facilitate the FGD and it states the main topics that need to be addressed. In carrying out FGD one should be relevant to the topic in question, take note of the possibility of language barrier, be polite, 
show genuine interest and be respectful to the respondents. For each of our two study areas; Bodibeng and Kareng, a focus group discussion was held, each consisting of 12 respondents. One consisted of key members in the farming community like the Kgosi, members from the Farmer's Committee as well as few farmers of all ages. With them we discussed issues like their perception on the characteristics of weather forecasts and their perceptions on the effect of agricultural policies implemented to improve the uptake of early warning scientific weather information.

\subsection{Measurement of Variables}

A 5-point Likert scale was used to measure and score a set of statements addressing cultural and psychosocial factors (e.g. traditionalism and fatalism), and the uptake of scientific weather information. The grand mean of the population plus or minus standard deviation $(\mathrm{X} \pm \mathrm{SD})$ was used to categorize the respondents by determining the low and upper limits of the categories. For instance, fatalism was practiced as 'Highly fatalistic'; 'Moderately fatalistic'; and 'Not fatalistic'. Traditionalism was categorized as 'Highly traditionalistic'; 'moderately traditionalistic'; and 'Not traditionalistic'. Uptake of information was categorized as 'High uptake'; 'Moderate uptake'; and 'Low uptake'. Farmers' age was measured in years. Income level was measured by the amount earned per month.

\subsection{Data Analysis}

The primary purpose of this study was to analyze the factors influencing the low uptake of early warning scientific weather information by local farmers. Therefore, this study utilized both qualitative and quantitative methods as methods of data analysis. Quantitative method was utilized when analyzing data from questionnaires administered with farmers. Raw data in numeric form on questionnaires were organized into tables, frequency tables and pie charts. Descriptive statistics (such as frequency, percentages, and measures of central tendency, pie and bar chats) were used to summarize the results. Raw data from open-ended questions and interviews were summarized into themes.

\section{Results and Discussion}

\subsection{Farmers' Demographic and Socio-Economic Attributes}

A total of 90 farmers were interviewed in two villages; Kareng and Bodibeng. The respondents consisted of both males and females, but the females were the dominant respondents in total. The overall gender distribution indicates that $70 \%$ of the respondents interviewed were females. 'African women are particularly known to possess indigenous knowledge which helps to maintain household security, particularly in times of drought and famine (Intergovernmental Panel on Climate Change [IPCC] 2007:457). In both villages, people found at home were mostly females and they explained that this is because males spend most of the time in cattle posts while they (females) take care of school children.

The average income for the farmers was BWP543.77 (US\$54.38) per month. Majority of the farmers (51.11\%) earned between BWP 251-BWP500 (US\$25.10-US\$50) per month. They supplemented their farming income with wages from the labor-intensive public works program - Ipelegeng. While $12.2 \%$ of farmers earned more than BWP500 (US\$50) per month, only $11.1 \%$ of farmers in the study villages barely had monthly income, earning less than BWP100 (US\$10). The average household size was about six persons. Some $26 \%$ of the respondents indicated that they had more than nine persons living in the same household, while the minimum household size of one person per household was ascribed to $3.3 \%$.

The average age of the farmers in the study area was 49 years. Small-scale farmers were differentiated by type of practice and age. Farmers' age distribution was skewed towards older age-groups, with the majority (23.3\%) being older than 60 years. Nevertheless, most farmers also fell in the age groups of 36-40, 41-45, and 46-50. Also, $17.7 \%$ of the respondents were aged between 20 and 30 . Having more old people engaged in farming could be a result of technology, migration, modernity and other social factors that are prevalent today which impact on younger generation more than they do with older generation. Farming in Ngamiland District is categorized into three; pastoral, arable and mixed farming. Data revealed that $63.3 \%$ of the people in two villages practice both arable and pastoral farming (mixed farming). Despite unfavorable weather conditions, $17.8 \%$ of the respondents were involved in crop farming while $18.9 \%$ engaged in pastoral farming. Besides farming, respondents engaged in other means of livelihoods. For instance, data show that $40 \%$ of the farmers work in labor-intensive public works programme, Ipelegeng. Even though they complained that it was inconvenient and unreliable, they indicated that the programme significantly helped them when farm production was low. As earlier indicated, majority of farmers were above 60 years of age, thus $23.3 \%$ of the farmers rely on old age pension to supplement the little they get from farming. Civil servants were represented by $10 \%$; two of these civil servants were 
drivers at the clinic and Kgotla (Note 1) and others indicated that they worked at Kareng Primary School and Bodibeng Primary School respectively. More importantly, 26.7\% of the farmers indicated that they relied on other means of livelihoods like roofing traditional huts, selling wild fruits and some other unspecified part time jobs.

In terms of education level, analysis reveals that $24.4 \%$ of farmers had no formal education and $23.3 \%$ had Primary School Leavers Examination (PSLE) certificate. Most of the farmers were old aged, as such majority of them were likely to have no formal education as it was not common during their times. They indicated that in their youth they spent most of their time at cattle posts, so they did not consider education that much. The results indicate that this lack of education hindered farmers from understanding the scientific weather messages and putting them into practice. While $22.2 \%$ of the respondents acquired junior secondary education, only $7.8 \%$ had senior secondary education. The results also indicate that farmers have low education, but it is interesting to find out that some have up to Cambridge O'level who are likely to be the younger farmers. The farmers indicated that educational level is very important when it comes to understanding the scientific weather information and making farming decisions. This was proven during discussions because those with higher level of education were able to give informed suggestions.

\subsection{Effects of Utilization of Indigenous Knowledge on the Uptake of Early Warning Scientific Weather Information}

The results (Table 1) indicate that a cumulative $86 \%$ of farmers were "strongly confident" and "confident" in the efficacy of local knowledge in weather forecasting, a total of $8.9 \%$ indicated that they were "strongly not confidence" and "not confident" about the efficacy of indigenous knowledge weather forecasting. Also, some 56\% asserted that they always use IK in making farming decisions and activities. On the other hand, $52.3 \%$ indicated confidence in scientific weather forecasting. Some $19 \%$ of the respondents indicated that they always use scientific knowledge and information in their farming activities.

Table 1. Frequency distribution of farmers by level of confidence in IK and scientific knowledge

\begin{tabular}{llllll}
\hline Statement & $\begin{array}{l}\text { Strongly } \\
\text { confident }\end{array}$ & confident & Neutral & $\begin{array}{l}\text { Not } \\
\text { confident }\end{array}$ & $\begin{array}{l}\text { Strongly } \\
\text { confident }\end{array}$ \\
\hline $\begin{array}{l}\text { Efficacy of indigenous knowledge } \\
\text { in weather forecasting }\end{array}$ & $41(46)^{* *}$ & $36(40)$ & $5(5.6)$ & $6(6.7)$ & $2(2.2)$ \\
\hline $\begin{array}{l}\text { Efficacy of scientific knowledge in } \\
\text { weather forecasting }\end{array}$ & $15(16.7)$ & $32(35.6)$ & 19 & $9(10.0)$ & $15(16.7)$ \\
\hline
\end{tabular}

Notes: **Percentages in parenthesis. Source: Field survey, 2012

A total of $94 \%$ of the farmers opined that they have knowledge of IK. However, $62 \%$ of them affirmed that they had knowledge of scientific weather information. Some $73 \%$ disagreed and refuted the notion of discarding IK; which is deemed to be environmentally and farmer friendly. However, $87 \%$ of farmers preferred that scientific weather knowledge and IK be combined and used simultaneously to complement each other in bringing development and sustainability in the agricultural system. This view is also held by (Chinlampianga 2011) who asserts that knowledge on weather and climate held by local and tribal communities can play significant role in the agricultural production. The experience and knowledge of old generations have largely contributed to sustainability of community in their day to day living, and in their health-care and agricultural systems. To buttress this, a group of farmers in Kareng (during FGD) indicated that:

'Indigenous weather knowledge could indeed be beneficial as local knowledge forecasts are usually done seasonally while scientific weather forecasts are done daily. The scientific weather forecasts are also done for various places whereas local knowledge weather forecasts are specific for a place, where a farmer is located at a point in time. Emphasis on combining the two could actually fill the gaps and enhance reliable predictions.'

\subsection{Types of Weather Information Received by Farmers}

Analysis reveals that about $80 \%$ and $76 \%$ of the respondents receive mainly rainfall and temperature information from Department of Meteorological Services, respectively. Farmers indicated that unreliable rainfall and harsh temperature conditions severely affect them as the entire farming system is more dependent on rainfall and 
temperature conditions. They indicated that extremes in these weather conditions caused high mortality of livestock and scorching of crops. Respondents also indicated that they received information on winds (58\%), clouds (52\%) and sunshine (49\%). When specifically questioned if they understood this information, $65.6 \%$ of the farmers asserted that they understood it whereas $34.4 \%$ had little understanding of the information. Interviews with key informants indicated that there was lack of skills among the institutions responsible for communicating the information, suggesting the importance of training personnel in communication skills. An effective communicator should be sensitive to the nature of his or her language (Mukhala, 2000). Majority of the farmers in Kareng and Bodibeng are OvaHerero, San and Bakgalagadi. However, the local language which is the medium of communicating weather information is Setswana, and not the first language of those people. It thus becomes difficult for them to properly imbibe information communicated in Setswana. Farmers also expressed concern about the use of English in disseminating information. They suggested that the Department of Meteorological Services (DMS) should consider using some of the local languages to drive the message home.

\subsection{Timeliness of Information}

The lack of efficiency in delivery also presented challenges to farmers. The interface between the time the forecast is issued and when it finally reaches the users is known as the lag-time (Stern and Easterling 1999). Most farmers (66.7\%) experienced no time lag in information delivery as they believed that they received daily weather messages through the radio and TV. Some $33.3 \%$ of the respondents who indicated that they felt the messages reach them late had reservations about not having any reliable mechanism of delivery. They indicated that they lived in cattle posts or had no money to buy radios through which they could have easily accessed information. For instance, one farmer said that the forecasts may not immediately reach the end-users a month late, when they had already planted their crops thus making the forecast of little or no use to them.

\subsection{Farming Related Problems Influencing the Uptake of Scientific Weather Information}

Farmers were asked if a) they encountered any weather-related problems or challenges in their farming activities and b) to identify them if any. It was assumed that these problems influenced the uptake of scientific weather information because when farmers are faced with these problems; their focus is on their immediate needs. Hence, they tend to lose focus or interest in scientific weather information.

All the interviewees indicated they have encountered problems in their farming activities. The farmers stated environmental problems such as unreliable and low rainfall, and high temperatures. Most farmers (96.7\%) indicated that their farming production suffered because of low, unreliable rainfall. Small-holder farmers depend on the availability of rain water for domestic use, livestock and ploughing. About $92.2 \%$ of the farmers (Table 2) also showed that one of the problems that hindered them from excelling in farming is high temperatures. According to interviewees, unavailability of rainfall and high temperature leads to drought hence there is high mortality of livestock and poor or no harvest. They indicated that hot sunshine dries up the soil and scorches their plants. Harsh winds were also noted as some $84.4 \%$ of respondents pointed it out as one of the problems severely affecting them. They indicated that usually very low temperatures which frost plants are not common in this area, but mostly frustrated by the harsh ones which sweep away plants thus destroying them. Other environmental factors plaguing farmers are predators and herbivores. Farmers went on to express their concern about poor farming equipment they are using as well as the outbreak of diseases like foot-and-mouth disease. However, these were not part of the focus of the study, hence they were excluded from the analysis.

Table 2. Frequency of farmers by identified farming problems

\begin{tabular}{lcc}
\hline Farming problem & *Frequency $(\mathbf{n}=\mathbf{9 0})$ & Percentage $\mathbf{( \% )}$ \\
\hline Inadequate rainfall & 87 & 96.7 \\
Harsh winds & 76 & 84.4 \\
High temperatures & 83 & 92.2 \\
\hline
\end{tabular}

Notes: *Multiple responses. Source: Field survey 2012

\subsection{Some Value Orientations of Farmers and Their Implications for Information Uptake}

\subsubsection{Fatalism}

The distribution of farmers by their disposition towards fatalism in relation to the uptake of early warning scientific weather information (Table 3), indicates that $33.3 \%$ of the farmers agreed or strongly agreed with the 
statement that 'There is no amount of scientific weather information that can bring about an improvement in agricultural production and productivity', whereas $60 \%$ either disagreed or strongly disagreed with the statement. Farmers had indicated that they believe that if the scientific weather information could be well communicated, it would really benefit them in their farming activities. Most respondents $(80 \%)$ either agreed or strongly agreed with statement that 'Regardless of human effort and intervention in preventing natural danger, what will be will still be'. Also, $76.7 \%$ of them either agreed or strongly agreed that 'Bad weather conditions are an act of the gods or God'. For instance, during one of our interview sessions in Kareng one 80-year old man claimed that, '...severe weather conditions are perpetuated by young generations who fail to observe our traditions and customs (taboos: meila). Therefore, our ancestors are displeased and have cursed the earth to be infertile and fruitless.'

Table 3. Farmers' disposition towards fatalism

\begin{tabular}{llllll}
\hline Statement* & $\begin{array}{l}\text { Strongly } \\
\text { Agree }\end{array}$ & Agree & Neutral & Degree & $\begin{array}{c}\text { Strongly } \\
\text { Agree }\end{array}$ \\
\hline $\begin{array}{l}\text { 1. There is no amount of scientific } \\
\text { weather information that can bring } \\
\text { about an improvement in agricultural } \\
\text { production and productivity }\end{array}$ & & & & & \\
\hline
\end{tabular}

Majority (78.9\%) of the farmers opined that 'There is no use trying to change a situation which appears irredeemable'. While $72.2 \%$ of the respondents agreed or strongly agreed that they can no longer do anything about the unpredictable weather conditions which they experience now-a-days, $21.1 \%$ of them either strongly disagreed or disagreed with this. Nonetheless, most farmers $(87.8 \%)$ agreed or strongly agreed with the statement 'I do not think I want to exert my energy on what I think I cannot influence'. From another perspective, some $64.5 \%$ of the farmers interviewed either agreed or strongly agreed to the statement 'It is good to remain quiet and accept our fate as it comes'. However, $32.2 \%$ had a contrary opinion about the statement.

Table 4 shows the distribution of farmers by their level of disposition towards fatalism. Some $11 \%$ of the farmers whose score fall within the lower range (0.01-2.99) are categorized as not fatalistic; they are more likely to embrace change and as such will adopt scientific weather knowledge, all things being equal. However, the middle range (3.00-4.44), are neutral and have a high proportion of $73.3 \%$. This might imply that most farmers' attitudes are neither here nor there in relation to resignation to fate; this affects the uptake of scientific weather information. The upper range of (4.45-5.00), which constituted $14.4 \%$ of the farmers are categorized as fatalistic 
and are unlikely to adopt scientific weather knowledge introduced to them by the DMS. Such individuals may discontinue using scientific weather knowledge altogether if at all they once used the early warning information (Kolawole et al. 2003).

Table 4. Level of farmers' disposition towards fatalism

\begin{tabular}{lcc}
\hline Fatalistic & Range & Percentage (\%) \\
\hline Not fatalistic & $1.00-2.99$ & 12.2 \\
Moderately fatalistic' & $3.00-4.44$ & 73.3 \\
Highly Fatalistic & $4.45-5.00$ & 14.4 \\
\hline
\end{tabular}

Source: Field survey, 2012

\subsubsection{Traditionalism}

A cumulative $83.3 \%$ of farmers (Table 5) strongly agreed and agreed with the statement: 'Our ancestors and forefathers had a way of going about their farming activities which I will continue to stick to'. Farmers asserted that their forefathers had ways of achieving better in farming which they would like to uphold. While $51.1 \%$ of the farmers either agreed or strongly agreed with the statement that 'Modernization cannot help and as such I will continue to follow what our forefathers have been doing in terms of farming activities', some $45.6 \%$ of them strongly disagreed and disagreed with the statement. Also, an overwhelming majority (97.8\%) of the farmers agreed and strongly agreed with the statement 'I like the traditions of our people and I will forever observe them'. Also, $47.8 \%$ of the farmers opined that 'There are no outsiders' ideas on weather forecasting as better as the ones in my community'. However, some $43 \%$ of these farmers disagreed with the statement. Whereas some $66.6 \%$ of the respondents had the opinion that 'It is difficult to implement foreigners' ideas and innovations', majority $(92.2 \%)$ strongly agreed and agreed with the statement 'I like to continue to practice farming as I inherited it from my forefathers'.

Table 5. Farmers' disposition towards traditionalism

\begin{tabular}{|c|c|c|c|c|c|}
\hline Statement* & $\begin{array}{l}\text { Strongly } \\
\text { Agree }\end{array}$ & Agree & Neutral & Disagree & $\begin{array}{l}\text { Strongly } \\
\text { Disagree }\end{array}$ \\
\hline $\begin{array}{l}\text { 1. Our Ancestors and forefathers had a way of } \\
\text { going about their farming activities, which I } \\
\text { will continue to stick to. }\end{array}$ & $36(40.0)$ & $\begin{array}{c}39 \\
(43.3)\end{array}$ & $2(2.2)$ & $11(12$ & $2(11)$ \\
\hline $\begin{array}{l}\text { 2. Modernization cannot help and as such I will } \\
\text { continue to follow what our forefathers have } \\
\text { been doing in terms of farming activities }\end{array}$ & $19(21.1)$ & $\begin{array}{c}27 \\
(30)\end{array}$ & $3(3.3)$ & $36(40)$ & $5(5.6)$ \\
\hline $\begin{array}{l}\text { 3. I like the traditions of our people and I will } \\
\text { forever observe them }\end{array}$ & $65(72.2)$ & $\begin{array}{c}23 \\
(25.6) \\
\end{array}$ & - & $2(2.2)$ & - \\
\hline $\begin{array}{l}\text { 4. There are no outsiders' ideas on weather } \\
\text { forecasting as better as the ones in my } \\
\text { community. }\end{array}$ & $14(15.6)$ & $\begin{array}{c}29 \\
(32.2)\end{array}$ & $8(8.9)$ & $34(37.8)$ & $5(5.6)$ \\
\hline $\begin{array}{l}\text { 5. It is difficult to implement foreigners' ideas } \\
\text { and innovations }\end{array}$ & $21(23.3)$ & $\begin{array}{c}39 \\
(43.3) \\
\end{array}$ & $3(3.3)$ & $24(26.7)$ & $3(3.3)$ \\
\hline $\begin{array}{l}\text { 6. I like to continue to practice farming as I } \\
\text { inherited it from my forefathers. }\end{array}$ & $37(41.1)$ & $\begin{array}{c}46 \\
(51.1)\end{array}$ & - & $6(6.7)$ & $1(.1)$ \\
\hline
\end{tabular}

Notes: *Multiple responses; **Percentages in parenthesis. Source: Field survey, 2012

The inference from these analyses suggests that farmers find it comfortable and safe to stick to their ways of 
doing things, which they have tested overtime and in which they are well versed. They exhibited fear of change and the perceptions of possible loss of own culture and identity may have frightened them. Local farmers indicated that they will continue to embrace their traditions as they find them to be adaptive and applicable in their communities.

The distribution of farmers by their level of disposition towards traditionalism (Table 6). Indicates that the lower range (1.00-2.99) constitutes $15.6 \%$ of the farmers who are categorized as not traditionalistic. The middle range (3.12-4.47) constitutes farmers who are neutral or undecided (64.4\%). Modernization and urbanization also negatively affect or erode traditionalism. Some $20.0 \%$ of the farmers fell within the upper range (4.45-5.00) who are categorized as being traditionalistic in their dispositions towards change programs.

Table 6. Farmers' level disposition towards traditionalism

\begin{tabular}{lcc}
\hline Traditionalism & Range & Percentage (\%) \\
\hline Not Traditionalistic & $1.00-3.11$ & 15.6 \\
Moderately traditionalistic & $3.12-4.47$ & 64.4 \\
Highly traditionalistic & $4.48-5.00$ & 20 \\
\hline
\end{tabular}

Source: Field survey, 2012

\subsection{The Uptake of Local and Scientific Weather Information}

The distribution of farmers by how they uptake both indigenous and scientific weather information/knowledge (Table 7) indicates that $76.6 \%$ of farmers agreed or strongly agreed with the statement 'I do listen to scientific weather forecast information'. While $36.6 \%$ of the farmers agreed and strongly agreed with the statement 'I do not find weather reports from the Department of Meteorological Services useful in any way', some $56.7 \%$ of them either strongly disagreed or disagreed with this statement. Majority (68.9\%) of the farmers agreed with the statement: 'I only rely on local knowledge in predicting the weather conditions in relation to farming activities'. These include observation of birds' movements; star and moon constellations; flowering and ripening of fruits of certain trees; clouds gathering and their directions; livestock behavior and others. For instance, during one of our focus group discussions in Kareng, one aged farmer stated that:

'Around September we could observe the clouds and then be able to tell if there will be rain or not. If the clouds are scattered and white it shows that there would be less or no rain but if the clouds are gathered and dark it indicates rain. Thick and dark clouds arranged perpendicular to the orbit of the sun in the morning, with lower temperatures and slight winds are believed to indicate the advent of the rains.' Winds from north to south usually reflect a lot of rain, but if it blows the opposite direction it shows low rain. Strong whirlwinds are believed to result in droughts. Birds and animals are observed; the appearance of many korwe (hornbill; Bucerotidae) indicates a year of drought. Appearance of other birds like Peolwane (swallow; Hirundinidae) and Uruutaote portend rains and amount of rainfall are determined by their chirpings. Donkeys mostly mate and bray during the rainy period while cattle usually indicate the direction of rain and place where it will rain by raising their noses towards that direction. Also, if fruits of trees like Motlopi (shepherd tree), Moretlwa (brandy bush) and Moretologa (Small sour plum) ripe early around September, they indicate early rainfall. Star and moon constellations like moon halo reveal harsh winters and plenty of rain'.

Farmers showed that they understand their local forecasts better; hence they rely on them more than on scientific weather forecasts. About $83.3 \%$ of farmers strongly agreed or agreed that 'Local knowledge is farmer and environmentally friendly'. The majority $(86.7 \%)$ either agreed or strongly agreed to the statement 'In making farming decisions, I consult with the elders and not Department of Meteorological Services". On further asking the farmers, they explained that they had never come into personal contact with the meteorologists. Nonetheless, some $62.2 \%$ agreed with the statement: 'The weather information from the Department of Meteorological Services' is effective'. Probed whether they would use the forecast, they gave examples as to how they might use it and showed that they had many ideas on how to operationalize the information. Most of the participants said that they would respond to a forecast for example; for above normal rain but would ignore the forecast if it predicted below normal rain. This did not stop them from giving suggestions on how they might use the below normal forecast if they did believe it. Whereas $17.8 \%$ of farmers agreed to the notion 'Local knowledge is old 
fashioned and needs to be discarded', most farmers (80\%) rejected the notion. While $42.2 \%$ of farmers agreed that: 'Weather information as forecasted by the Department of Meteorological Service cannot be relied upon', some $46.7 \%$ disagreed with the statement. From their past experiences, the predictions are not very accurate as what the meteorologists usually forecast does not come to pass in reality. For example, one skeptical farmer claimed that '...last year a very good season was predicted with higher rainfalls, but this never happened as we are now experiencing signs of droughts'. This shows that the credibility of the forecast, built on the accuracy of past forecasts and the forecast communicators' reputation, can also restrict uptake (Patt and Gwata 2002). The farmers signified that the weather forecasts are usually in probabilistic nature rather than quantified, which makes them doubtful about it since they are not comfortable dealing with probabilities. Ziervogel (2003) shared the same sentiments as he elaborated that, 'If the forecasts were designed as a 'quantification of the danger of climate variability' for example, 'it might allow users to accept the forecasts more easily'.

Table 7. Farmers' uptake of IK and scientific knowledge

\begin{tabular}{|c|c|c|c|c|c|}
\hline Statement* & $\begin{array}{l}\text { Strongly } \\
\text { Agree }\end{array}$ & Agree & Neutral & Disagree & $\begin{array}{l}\text { Strongly } \\
\text { disagree }\end{array}$ \\
\hline $\begin{array}{l}\text { 1. I do listen to scientific weather forecast } \\
\text { information. }\end{array}$ & $\begin{array}{l}13 \\
(14.4)^{* *}\end{array}$ & $\begin{array}{l}56 \\
(62.2)\end{array}$ & $1(1.1)$ & $15(5)$ & $5(5.6)$ \\
\hline $\begin{array}{l}\text { 2. I do not find weather reports from the } \\
\text { Department of Meteorological Services useful } \\
\text { in any way }\end{array}$ & $3(3.3)$ & $\begin{array}{l}30 \\
(33.3)\end{array}$ & $6(6.7)$ & $46(51.1)$ & $5(5.6)$ \\
\hline $\begin{array}{l}\text { 3. I only rely on local knowledge in predicting the } \\
\text { weather in relation to farming activities. }\end{array}$ & $26(28.9)$ & $\begin{array}{l}36 \\
(40.0)\end{array}$ & $\begin{array}{l}12 \\
(13.3)\end{array}$ & $15(16.7)$ & $1(1.1)$ \\
\hline $\begin{array}{l}\text { 4. Local knowledge is farmer and } \\
\text { environmentally friendly }\end{array}$ & $47(52.2)$ & $\begin{array}{l}28 \\
(31.1)\end{array}$ & $6(6.7)$ & $8(8.9)$ & $1(1.1)$ \\
\hline $\begin{array}{l}\text { 5. In making farming decisions, I consult with the } \\
\text { elders and not Department of Meteorological } \\
\text { Services }\end{array}$ & $51(56.7)$ & $\begin{array}{l}27 \\
(30)\end{array}$ & $\begin{array}{l}10 \\
(11.1)\end{array}$ & $2(2.2)$ & $2(2.2)$ \\
\hline $\begin{array}{l}\text { 6. The weather information from the Department } \\
\text { of Meteorological Services is effective }\end{array}$ & $12(13.3)$ & $\begin{array}{l}44 \\
(48.9)\end{array}$ & $\begin{array}{l}10 \\
(11.1)\end{array}$ & $17(18.9)$ & $7(7.8)$ \\
\hline $\begin{array}{l}\text { 7. Local knowledge is old fashioned and needs to } \\
\text { be discarded }\end{array}$ & $5(5.6)$ & $\begin{array}{l}11 \\
(12.2)\end{array}$ & $2(2.2)$ & $27(30)$ & $45(50)$ \\
\hline $\begin{array}{l}\text { 8. Weather information as forecasted by the } \\
\text { Department of Meteorological Services cannot } \\
\text { be relied upon }\end{array}$ & $12(13.3)$ & $\begin{array}{l}26 \\
(28.9)\end{array}$ & $\begin{array}{l}10 \\
(11.1)\end{array}$ & $37(41.1)$ & $5(5.6)$ \\
\hline $\begin{array}{l}\text { 9. I have not adopted any weather information } \\
\text { aside the local knowledge- }\end{array}$ & $10(11.1)$ & $\begin{array}{l}19 \\
(21.1)\end{array}$ & $\begin{array}{l}10 \\
(11.1)\end{array}$ & $41(45.6)$ & $10(11.1)$ \\
\hline $\begin{array}{l}\text { 10. I feel scientific weather information is difficult } \\
\text { to imbibe because they are too complex to } \\
\text { interpret }\end{array}$ & $27(30)$ & $\begin{array}{l}28 \\
(31.1)\end{array}$ & $2(2.2)$ & $28(31.1)$ & $5(5.6)$ \\
\hline $\begin{array}{l}\text { 11. I will prefer that we combine both scientific } \\
\text { weather knowledge and local knowledge in } \\
\text { weather forecasting to forestall agricultural } \\
\text { failure. }\end{array}$ & $55(61.1)$ & $\begin{array}{l}24 \\
(26.7)\end{array}$ & $3(3.3)$ & $3(3.3)$ & $5(5.6)$ \\
\hline
\end{tabular}

Notes: *Multiple responses; **Percentages in parenthesis. Source: Field survey 2012 
Some $32.2 \%$ of the respondents agreed or strongly agreed with the statement: 'I have not adopted any weather information aside those of local knowledge'. However, $56.7 \%$ of them disagreed with the statement. Most farmers $(61.1 \%)$ opined that: '... scientific weather information is difficult to imbibe because it is too complex to interpret'. They had the reservations that most of the words used are sounded jargons to them thus making it difficult for them to put the message into practice or adopt them in their farming decisions. Most of the farmers in Kareng and Bodibeng are San and OvaHerero and their first languages are not used to disseminate the information. During one interview, a Herero farmer elaborated that some Setswana words are used on these predictions, giving an example of 'mosarasarane' which means few drops of rain. He indicated that they are not familiar with these words, which results in low uptake of scientific weather information. The radio as the commonest mechanism of delivery does not allow them to ask questions for clarifications in cases they do not understand the disseminated information.

Most farmers (87.8\%) strongly agreed with the statement: 'I will prefer that we combine both scientific weather knowledge and local knowledge in weather forecasting to forestall agricultural failure'. Farmers opined that the combination of the two knowledges could help fill the gaps in the uptake. More importantly, the viewpoints of farmers in our investigations indicated that the uptake of early warning scientific weather information by local farmers is low. As, indicated in Table 7, 61.1\% of farmers who strongly agreed to combine IK and scientific knowledge in weather forecasting further suggests that majority of the farmers are neither here nor there as to whether to utilize local knowledge fully or adopt scientific weather information completely.

The distribution of farmers by the level of uptake of scientific weather information (Table 8) indicates that some $16.7 \%$ of the respondents (i.e. those categorized within the minimum range of between $(0.01-2.22)$ had a perceived low level of scientific weather information uptake. While $68.9 \%$ of the farmers fell within the middle range (2.23-2.92), indicating that they had a perceived moderate level of uptake of scientific weather information, only $14.4 \%$ of the farmers had a perceived high level of scientific weather information uptake.

Table 8. Level of farmers' uptake of IK and modern knowledge

\begin{tabular}{lcc}
\hline Uptake & Range & Percentage (\%) \\
\hline Low uptake & $1.00-2.22$ & 16.7 \\
Moderate uptake & $2.23-2.93$ & 68.9 \\
High uptake & $2.93-5.00$ & 14.4 \\
\hline
\end{tabular}

Source: Field survey, 2012

\subsection{Channels of Communication of Scientific Weather Information}

Table 9 below shows that $80 \%$ of the respondents in both villages receive scientific weather information mostly through the radio and one respondent indicated to have had exposure to print media but he was quick to point out that he did not have them on a regular basis. Radio is accessible to most of the farmers, however, the farmers could not hide their dissatisfaction as they lamented about poor network coverage during rainy season and that they sometimes run out of batteries hence missing scientific weather information. While majority $(97.7 \%)$ of the farmers indicated that they rarely meet with government extension officers; only $3.3 \%$ of the farmers indicated that they had received advice or information from the extension officers. They claimed that the only time they meet the extension officers is when they are distributing seeds. One agricultural officer in Kareng blamed the Department of Meteorological Services for failing to work with extension officers.

Table 9. Frequency of farmers by channel of communication

\begin{tabular}{llcc}
\hline Channel of Communication & Frequency $(\mathbf{n = 9 0 )}$ & Percentage $\mathbf{( \% )}$ \\
\hline 1. & Kgotla meetings & 3 & 3.3 \\
2. & Television & 30 & 33.3 \\
3. & Radio & 72 & 80 \\
4. & Print media & 1 & 1.1 \\
5. Agriculture extension agents & 3 & 3.3 \\
6. & Other farmers & 47 & 52.2 \\
\hline
\end{tabular}

Notes: *Multiple responses. Source: Field survey, 2012. 
Discussions on and sharing of scientific weather information were done by $52.2 \%$ of local farmers. The respondents indicated that they lack confidence and enthusiasm in the scientific weather information. Hence, they are not conversant with it. Some $33.3 \%$ of the farmers indicated that they received information through the television. There is a consensus that the existing channels of communication (most especially the radio) are relevant and accessible to the majority. However, farmers opined that the use of the radio has its own loopholes, as previous information cannot be retrieved.

The results of a chi-square analysis (Table 10) indicate that at $p \leqslant 0.01$ level of confidence, Kgotla meetings $\left(\chi^{2}\right.$ $=78.4)$, radio $\left(\chi^{2}=32.4\right)$, television $\left(\chi^{2}=10.4\right)$, print media $\left(\chi^{2}=86.0\right)$ and agricultural extension officers $\left(\chi^{2}=\right.$ 78.4) all had a statistically strong and significant association with the uptake of scientific weather information by the farmers. The inference is that all the variables that are significant in the analysis contribute immensely to the uptake of scientific weather information amongst local farmers in the study area. Majority of the farmers recommended that the Department of Meteorological Service should '...hold Kgotla meetings where farmers could be educated on scientific weather information'.

Table 10. Chi-Square analysis of channels of communication and the uptake of scientific weather information

\begin{tabular}{llll}
\hline Channels of Communication & $\chi^{2}$-Value & P-Value & Decision \\
\hline Kgotla meetings & $78.4^{* *}$ & 0.00 & Significant \\
Radio & $32.4^{* *}$ & 0.00 & Significant \\
TV & $10.0^{* *}$ & 0.00 & Significant \\
Print media & $86.0^{* *}$ & 0.00 & Significant \\
Agricultural extension officers & $78.4^{* *}$ & 0.00 & Significant \\
Other farmers & 0.18 & 0.673 & Not significant \\
\hline
\end{tabular}

Notes: ${ }^{*} \chi^{2}$ is significant at $\mathrm{P} \leqslant 0.01$. Source: Field survey 2012

Correlation analysis (Table 11) of the relationship between explanatory variables and uptake of scientific weather information by farmers indicate that at $\mathrm{p} \leqslant 0.01$ level of significance, there is a positive and significant correlation between farmer's education level $(\mathrm{r}=0.328)$ and the uptake of scientific weather information. The implication of the finding is that the more educated the farmer becomes; the more likely is he or she to prefer the use of scientific weather knowledge in farming. At $p \leqslant 0.05$ confidence level, a significant but negative correlation exists between farmer' $\mathrm{s}$ age $(\mathrm{r}=-0.223)$ and the uptake of scientific weather information. This implies that the younger the farmer is; the likely she or he will prefer to rely on scientific weather information. Traditionalism $(r=-0.268)$ also had a significant but negative correlation with the uptake of scientific weather information. This implies that the more farmers become traditionalistic, the less the adoption of scientific weather information. Income level $(r=0.008)$ and household size $(r=-0.050)$ had no significant correlation with the uptake of scientific weather information. However, the direction of relationship between income and uptake of scientific weather information suggests that the higher the income of the farmer, the more likely it is for him or her to adopt such information. High income may engender a high investment in farming and farming-related activities, and the higher the investment, the stronger the desire to succeed in the venture.

Table 11. Relationship between farmers' characteristics and uptake of scientific weather information

\begin{tabular}{|c|c|c|c|c|}
\hline Variable & 'r'value & $\begin{array}{c}\text { Co-efficient of } \\
\text { determination }\left(r^{2}\right)\end{array}$ & $\mathbf{b}$ & $\mathbf{t}$ \\
\hline Age & $-0.223^{*}$ & 0.050 & 0.002 & 0.726 \\
\hline Educational level & $0.328 * *$ & 0.108 & $0.032 *$ & $2.234^{*}$ \\
\hline Income level & 0.008 & 0.000 & -0.000 & -1.332 \\
\hline Household size & -0.050 & 0.003 & -0.004 & -0.343 \\
\hline Fatalism & $-0.338 * *$ & 0.115 & $-0.123 *$ & $-2.320 *$ \\
\hline Traditionalism & -0.268 & 0.057 & -0.039 & -0.673 \\
\hline
\end{tabular}


The results of the multiple regression analysis (Table 11) showed that farmers' education level $(\mathrm{t}=2.234 ; \mathrm{p} \leqslant$ 0.05 ) had a significant positive relationship with the uptake of scientific weather information. This implies that the higher the education level of the farmers, the more the chances that they will adopt, or uptake weather information introduced to them by the DMS. Conversely, there was a significant negative relationship between fatalism ( $\mathrm{t}=-2.320 ; \mathrm{p} \leqslant 0.05)$ and information uptake. It is then deduced that the more fatalistic the farmers are, the less the chances that they will adopt or uptake the introduced weather information. But this inference is counter-intuitive to the earlier findings that approximately $83 \%$ of the farmers were perceived to have either moderately or highly adopted the weather information introduced to them (Table 8), which indicates that farmers' tendency for fatalism (Table 4) may not necessarily have influenced their decision on the use of scientific weather information. In summary, $\mathrm{R}^{2}$ value (which is the coefficient of determination) shows that only $20.8 \%$ of the variations in $\mathrm{Y}$ is explained by the significant variables in the model. As reflected in the coefficient of multiple correlation $\mathrm{R},(\mathrm{R}=0.456)$, about $46.0 \%$ of the variation in $\mathrm{Y}$ is explained by all the predictor variables in the regression model. The computed statistical values then suggest that there are still many unknown predictors that may have been responsible for farmers' decisions on the uptake of weather information in the study area.

\section{Conclusion}

This study assessed the factors that influenced low uptake of early warning weather information by local farmers in some selected villages in north-western Botswana. These included farmers' demographic and psychosocial characteristics, information type and timelines, and farming-related challenges. It assessed the perceptions of farmers towards modern scientific weather information and determined the relationship between affinity for using indigenous knowledge and uptake of modern scientific weather information.

Demographic characteristics such as age and education had negative and positive correlations with uptake of scientific weather information, respectively. Kgotla meetings, TV, print media, agricultural extension agents and the radio showed a strong association with the uptake of scientific weather information or messages. While little or nothing can be done about age, the gap created by low level of education can be filled through continuous awareness creation and local-level training of farmers on the importance and use of modern scientific weather information. The significant positive relationship between farmers' educational level and the uptake of scientific weather information implies that farmers' literacy attainment will influence their favorable decision to adopt the introduced weather information, all things being equal. It is, therefore, important for the DMS and extension agencies to recognize the pertinent role of farmers' training and education, to enhance effective information delivery and use. The type of information availed to farmers on temperature, wind, cloud cover, rainfall and sunshine is appropriate for local use. However, this information needs to be communicated in local languages and in simple form to enhance farmers' ability to understand them. Timeliness and accessibility of information need to be improved through other communication channels including mobile phone SMS, or voice messages for quick transfer.

Farming-related challenges affected $84 \%$ to $96 \%$ of farmers in the study villages. This implies that most farmers may be hindered from adopting scientific weather information, thus engendering their inability to adapt to the changes in climatic conditions. There is need to avail resources to farmers to enhance their readiness to address challenges posed by climatic variability such as high temperature, unreliable rainfall and severe wind storms. Fatalism and traditionalism are factors, which are likely to impede the uptake of modern scientific weather information as indicated in the negative correlations between these factors. Farmers may find it difficult to live with climatic variations if they perceive them to be far beyond their imaginable capacity to adapt. To overcome these barriers, the implementation of appropriate training and functional adult learning programs is the only option to unfreeze all undesirable value orientations of information recipients for the purpose of achieving a desirable outcome (see Burnes 2004; Lewin 1947). Besides, it is also important for change agencies to consider the channel through which weather information is conveyed to the recipients. There is need to motivate small-scale, rural farmers and promote awareness of existing adaptation options. This can be done through community-level seminars, radio and television broadcasts as well as through mobile phone systems.

The study has also demonstrated that there is a negative relationship between affinity for indigenous knowledge and uptake of modern scientific information. Scientific weather information was believed to be complex to understand, and that modernization could not help farming activities, which indicates difficulty to adopt and implement foreign ideas and innovations. Most farmers (76.6\%) listen to radio messages on modern scientific weather forecasting and perceive the information to be useful (56.6\%). However, most only: (a.) rely on indigenous knowledge (68.8\%); (b.) consult elders not Department of Meteorological Services or Department of Agricultural Extension for farming decision-making (86.7\%); and (c.) consider indigenous knowledge as farmerand environmentally-friendly than scientific knowledge (83\%). This indicates that farmers use what they know, 
have trust in and understand. Compounded by lack of access to extension, uptake of scientific knowledge among rural farmers can only be wishful thinking if the extension agency and DMS do not prioritize personal contact and appropriate mass media approach in their delivery of information; the Kgotla platform, agricultural extension activities and radio programs are some of the veritable avenues through which farmers readily access information.

Worth noting is that most farmers (87.8\%) see a need to use both types of knowledge in order to benefit from their strengths. The smallholders' desire to collaborate with weather scientists in finding solutions to their problems through knowledge integration provides a ray of hope. Indeed, recent studies (Plotz \& Chambers, 2017; Kolawole et al., 2014a, 2014b) have provided a road map on how to integrate local weather forecasting knowledge with scientific weather knowledge. While Plotz and Chambers (2017) proffer a 4-point decision-making framework on how to combine the best attributes of the two forms of knowledge, Kolawole et al. (2014a, 2014b) outline a 9-point strategy for the formation of a partnership between local farmers and weather scientists to combat weather-related problems. At best, both propositions emphasize the need to recognize and situate ethno-meteorology within the context of western science through participatory modes of enquiry and engagement. The promotion of modern scientific weather information, coupled with well-resourced extension services, should be done in ways that may not or be perceived to denigrate indigenous knowledge. Sectoral departments also need to collaborate in addressing existing challenges; this is important for appropriate and timely response to environmental challenges particularly those emanating from climate change.

\section{Acknowledgements}

This work was funded by Botswana Department of Tertiary Education Funding (DTEF)to who we are grateful. We also thank the Botswana Department of Meteorological Services, the local communities in Bodibeng and Kareng and all those who supported this study in many ways.

\section{References}

Beal, G. M., Bohlen, J. M., \& Warland, R. H. (1968). Rural Value-orientations and Farm-Policy Positions and Actions. Research Bulletin (Iowa Agriculture and Home Economics Experiment Station), 36(561), 160-178. Retrieved from http://lib.dr.iastate.edu/cgi/viewcontent.cgi?article=1576\&context=researchbulletin

Bendsen, H., \& Meyer, T. (2002). The dynamics of the land use systems in ngamiland: changing livelihood options and strategies. Environmental Monitoring of Tropical Wetlands, 278-304.

Blench, R. (1999). Seasonal climate forecasting: who can use it and how should it be? Natural Resources Perspectives, 47, 1-4.

Burnes, B. (2004). Kurt Lewin and the planned approach to change: a re-appraisal. Journal of Management Studies, 41, 977-1002.

Chambers, R., Pacey, A., \& Thrupp, L. A. (Eds.). (1989). Farmers First: Farmer Innovation and Agricultural Research. Intermediate Technology Publications, London, UK.

Central Statistics Office [CSO]. (2011). 2011 Population and housing census preliminary results brief. Central statistics Office, Gaborone, Botswana. Retrieved from http://ecastats.uneca.org/aicmd/Portals/0/Census\%202011\%20Preliminary

Chenje, M. (2000). State of the Environment in the Zambezi Basin 2000. Southern African Research and Documentation Centre, Zimbabwe.

Chinlampianga, M. (2011). Traditional Knowledge, Weather Prediction and Bioindicators: A Case Study in Mizoram, Northeastern India. Indian Journal of Traditional Knowledge, 10(1), 207-11.

Dewes, W. (1993). Introduction. In. Davis, S. H., \& Ebbe K. (Eds.), Traditional Knowledge and Sustainable Development (pp. 3). Proceedings of a Conference held at the World Bank, Washington, DC, Sept. 27 - 28. Environmentally Sustainable Development Proceeding Series No. 4

Food and Agricultural Organisation [FAO]. (2001).

Gewald, J. B. (2001). El Negro, El Niño, Witchcraft and the Absence of Rain in Botswana. African Affairs, 100(401), 555-80.

Grenier, L. (1998). Working with Indigenous Knowledge. A Guide for Researchers. Ottawa: IDRC.

Inter-governmantal Panel on Climate Change [IPCC]. (2007). Climate Change 2007: Impacts, Adaptation and Vulnerability. In M. L. Parry, O. F. Canziani, J. P. Palutikof, P. J. van der Linden, \& C. E. Hanson (Eds.), Contribution of Working Group II to the Fourth Assessment Report of the Intergovernmental Panel on 
Climate Change. Cambridge University Press, Cambridge, UK.

Kolawole, O. D. (2015). Twenty reasons why local knowledge will remain relevant to development. Development in Practice, 25(8), 1189-1195. https://dx.doi.org/10.1080/09614524.2015.1078777

Kolawole, O. D., Wolski, P., Ngwenya, B., \& Mmopelwa, G. (2014). Ethno-meteorology and scientific weather forecasting: small farmers and scientists' perspectives on climate variability in the Okavango Delta, Botswana. Climate Risk Management, 4-5, 43-58. https://dx.doi.org/10.1016/j.crm.2014.08.002

Kolawole, O. D., Wolski, P., Ngwenya, B., Mmopelwa, G., \& Thakadu, O. (2014). Responding to climate change through joint partnership: Insights from the Okavango Delta of Botswana. World Journal of Science, $\begin{array}{llll}\text { Technology and Sustainable Development, } & 11(3), & \text { 170-181. }\end{array}$ https://dx.doi.org/10.1108/WJSTSD-06-2014-0010

Kolawole, O. D. (2013). Soils, Science and the Politics of Knowledge: How African Smallholder Farmers Are Framed and Situated in the Global Debates on Integrated Soil Fertility Management. Land Use Policy, 30(1), $470-84$.

Kolawole, O. D. (2009). Situating local knowledge within development agenda: some reflections. Consilience: The Journal of Sustainable Development, 1(2). Retrieved from $\mathrm{http} / /$ :consiliencejournal.readux.org/wp-content/uploads/2009/03/kolawole-final1.pdf

Kolawole, O. D. (2006). Local farmers' approach to soil conservation: lessons from Nigeria. Indilinga: African Journal of Indigenous Knowledge Systems, 5(1), 75-86.

Kolawole, O. D., Farinde, A. J., \& Alao, J. A. (2003). Other Side of Farmers' Adoption Behavior: Forms $\quad$ of Discontinuance. Journal of Extension Systems, 19(1), 70-80.

Kolawole, O. D. (2001). Local knowledge utilization and sustainable rural development in the $21^{\text {st }}$ Century. Indigenous Knowledge and Development Monitor, 9(3), 13-15.

Kruska, R. L., Reid, R. S., Thornton, P. K., Henninger, N., \& Kristjanson, P. M. (2003). Mapping Livestock-Oriented Agricultural Production Systems for the Developing World. Agricultural Systems, 77(1), 39-63.

Lewin, K. (1947). Frontiers in group dynamics. In Cartwright, D. (Ed.), 1952. Field Theory in social science: selected theoretical papers by Kurt Lewin (pp. 188-237). London: Social Science Paperbacks.

Mukhala, E. (2000). Meteorological services and farmers in Africa: is there shared meaning? University of Orange State South Africa. Retrieved from http://www.fao.org/sd/cddirect/cdre0051.htm

Ogburn, W. F. (1950). Social Change with Respect to Culture and Original Nature. New York: Viking.

Onyango, M. (2009). Kenya rainmakers called to the rescue to combat climate change. The Daily Tribune, 22 September, pp. 1-3. Retrieved November 11, 2010, from http://www.tribuneonline.org/commentary/20090922com6.html

Orlove, B., Roncoli, C., Kabugo, M., \& Majugu, A. (2010). Indigenous Climate Knowledge in Southern Uganda: The Multiple Components of a Dynamic Regional System. Climatic Change, 100(2), 243-265.

Osabuohien, E. (2014) Handbook of Research on In-Country Determinants and Implications of Foreign Land Acquisitions. Hershey PA USA: IGI Global.

Patt, A., \& Gwata, C. (2002). Effective seasonal climate forecast applications: examining constraints for subsistence farmers in Zimbabwe. Global Environmental Change: Human and Policy Dimensions, 12(3), $185-95$.

Perrings, C., \& Stern, D. I. (2000). Modelling Loss of Resilience in Agroecosystems: Rangelands in Botswana. Environmental and Resource Economics, 16(2), 185-210.

Plotz, R. D., \& Chambers, L. E. (2017). The best of both worlds: a decision-making framework for combining traditional and contemporary forecast systems. Journal of Applied Meteorology and Climatology, 56, 2377-2392.

Roncoli, C., Ingram, K., \& Kirshen, P. (2002). Reading the Rains: Local knowledge and Rainfall forecasting in Burkina Faso. Taylor and Francis, USA

Seanama Conservation Consultancy. (2012). Botswana National Report for the United Nations Conference on Sustainable Development. Retrieved from https://sustainabledevelopment.un.org/content/documents/1006National\%20Report\%20-\%20Botswana.pdf 
Speranza, C. I., Kiteme, B., Ambenje, P., Wiesmann, U., \& Makali, S. (2010). Indigenous knowledge related to climate variability and change: insights from droughts in semi-arid areas of former Makueni District, Kenya. Climatic Change, 100(2), 295-315.

Stern, P. C., \& Easterling, W. E. (Eds.). (1991). Making climate forecasts matter. National Academy Press, Washington DC.

Thornton, P. K., Jones, P. G., Ericksen, P. J., \& Challinor, A. J. (2010). Agriculture and food systems in sub-Saharan Africa in a $4^{\circ} \mathrm{C}+$ world. Philosophical Transactions of the Royal Society of London A: Mathematical, Physical and Engineering Sciences, 369(1934), 117-136. Retrieved from http://rsta.royalsocietypublishing.org/content

Warren, D. M. (1991). Using Indigenous Knowledge in Agricultural Development. World Bank Discussion Papers. The World Bank, Washington, DC.

Ziervogel, G. (2004). Targeting Seasonal Climate Forecasts for Integration into Household Level Decisions:the Case of Smallholder Farmers in Lesotho. The Geographical Journal, 70(1), Retrieved from https://onlinelibrary.wiley.com/doi/full/10.1111/j.0016-7398.2004.05002.x

\section{Note}

Note 1. The Kgotla is the local administration's seat of power and traditional forum through which pertinent matters affecting people's wellbeing are debated at the community level.

\section{Copyrights}

Copyright for this article is retained by the author(s), with first publication rights granted to the journal.

This is an open-access article distributed under the terms and conditions of the Creative Commons Attribution license (http://creativecommons.org/licenses/by/4.0/). 